\title{
楆
}

\section{Kan die GKSA na 150 jaar beskou word as 'n stagnante kerkgemeenskap? Ekumenies beoordeel}

\author{
C.J. Smit \\ Skool vir Kerkwetenskappe \\ Potchefstroomkampus \\ Noordwes-Universiteit \\ POTCHEFSTROOM \\ E-pos: neelssmit@lantic.net
}

\begin{abstract}
Should the RCSA after a period of 150 years be considered as a stagnated church community? Evaluated from the point of view of ecumenicism
\end{abstract}

The question is whether the Reformed Churches in South Africa (RCSA) should be considered as an isolated and thus a stagnated church community. To answer this question the development of ecumenicism in the RCSA should be traced. This could only be done after an examination of the Scriptural and historical meaning of the term "ecumenicism". From the acts of the synods of the RCSA it is very clear that during the three phases of half a century each in the existence of the RCSA, from 1859 onwards, a very high premium was put on ecumenical relations. The goal of these ecumenical relations was always pointed out as church unity.

In this contribution the conclusion is made that the RCSA does not see herself as a church community who disposes exclusively of the truth of the Word. Church isolation - and therefore church stagnation - is clearly not part of the RCSA's agenda; on the contrary, church isolation was always firmly contested by the RCSA on the basis of the Scriptures. The incentive to bring together churches of reformed origin, in the interior and abroad, was always part of the RCSA's view on what the church really stands for.

However, there is a significant deficiency that should be noted. The specific meaning that Jesus adds to the concept "oikoumené" (Matt. 24:14), namely the proclamation to "all the na- 
tions" of the whole world ("oikoumené") regarding the world to come (Heb. 2:5) is not sufficiently emphasised but in actuality it is downplayed.

\section{Opsomming}

\section{Kan die GKSA na 150 jaar beskou word as 'n stagnante kerkgemeenskap? Ekumenies beoordeel}

Die vraagstelling is of die Gereformeerde Kerke in Suid-Afrika (GKSA) as 'n geïsoleerde en derhalwe 'n stagnante kerkgemeenskap gesien moet word. Hierdie vraag word beantwoord deur die ontwikkeling van die GKSA ten opsigte van ekumenisiteit na te gaan, nadat die term "ekumenisiteit" Skriftuurlik en histories ontleed is. In drie fases van 'n halfeeu elk in die bestaan van die GKSA blyk uit die Handelinge van sinodes dat hierdie kerkgemeenskap vanaf hulle ontstaan in 1959 'n besonder hoë premie op ekumeniese verhoudings geplaas het. Hierdie ekumeniese verhoudings met ander gereformeerde kerke wêreldwyd is deurentyd gerig op ontwikkeling tot kerkeenheid.

Die gevolgtrekking word gemaak dat die GKSA hulleself nie as 'n kerkgemeenskap beskou wat alleen en uitsluitlik oor die waarheid van die Woord beskik nie. Kerklike isolasie, en derhalwe kerklike stagnasie, is klaarblyklik nie deel van die GKSA se agenda nie; trouens, isolasie is aantoonbaar deur die GKSA op grond van die Woord bestry. Die dryfveer om kerkgemeenskappe in eenheid saam te snoer, in die binneland én die buiteland, was van vroeg af deel van die GKSA se kerkbeskouing.

Tog is daar 'n opvallende leemte wat aangemerk moet word. Die betekenisaspek wat Jesus aan die begrip "oikoumené" toevoeg (Matt. 24:14), naamlik die verkondiging van die evangelie aan "al die nasies" in die "hele wêreld" ("oikoumené") met die oog op die "toekomstige wêreld" (Heb. 2:5) is nie genoegsaam beklemtoon nie, maar in betekenis eintlik verskraal.

\section{Inleiding}

Hierdie artikel waarin die GKSA in die konteks van sy ekumeniese bande beoordeel word, word ter huldiging van prof. A. le R. du Plooy aangebied uit 'n persoonlike vriendskapsband van veertig jaar, maar ook uit 'n diepe waardering vir sy bydrae in die GKSA waarin die ekumene 'n oorkoepelende rol vervul deur die loop van meer as drie dekades. (Die omvang en blywende waarde van sy bydrae moet nog bereken word.) 
Prof. Du Plooy se hele bediening as predikant, akademikus, dekaan van die Fakulteit Teologie en kerkregraadgewer in die GKSA, asook in ander wêrelddele ten opsigte van ander kerkgemeenskappe, staan in die teken van sy ekumeniese gerigtheid. Met die vermoë om besonderhede in samehang met die geheel te beoordeel, konstrueer hy sy advies telkens vanuit 'n beginselkern na die geheelbeeld van die praktyk. In sy kerkreg kom die plaaslike kerk telkens in die universele kerk tereg, en die universele kerk in die plaaslike kerk.

Die vraagstelling wat hier nagegaan word, is die volgende: Kan 'n neiging tot isolasie, en derhalwe 'n tendens van stagnasie, as kenmerk van die Gereformeerde Kerke in Suid-Afrika (GKSA) na 150 jaar aangemerk word? Moet die GKSA beskou word as 'n kerkgemeenskap wat deur die loop van 'n anderhalwe eeu tevrede was om die hele waarheid van die koninkryk slegs in eie oordele en gebruike te vind, ondanks beskouings én ontwikkeling van beskouings wêreldwyd in die geledere van kerkgemeenskappe uit die gereformeerde tradisie rondom die GKSA?

Om die sentrale vraag wat hier gestel word, te beantwoord, sal 'n beeld van die GKSA se ekumeniese beskouings en ontwikkelings deur die gang van 150 jaar weergegee moet word - hoofsaaklik aan die hand van primêre bronne, dit wil sê, amptelike besluite van sinodes van die GKSA. Daarom weerspieël die bibliografie in 'n groot mate die Handelinge van die GKSA se sinodes wat in die artikel gebruik is.

Dit is ook van belang om 'n raamwerk van die aard van ekumenisiteit in die gereformeerde tradisie daar te stel, waarbinne die uitlewing van die ekumene in die GKSA beoordeel kan word. Derhalwe word die betekenis van ekumenisiteit eerste aan die orde gestel.

\section{Die begrip ekumenisiteit}

Die begrip ekumenisiteit se wortels lê in die Nuwe Testament. Dit kom van die Griekse woord, oikoumené. Aanvanklik het hierdie woord op "bewoonde aarde" gedui (Matt. 24:14; Luk. 4:5; 21:26; Op. 3:10). Hiervolgens het die term ekumene allereers die betekenis van "betrekking hê op die hele bewoonde aarde", of, "verteenwoordigend wees van die hele bewoonde aarde". In die hellenistiese kultuurwêreld is die oorspronklike geografiese inhoud van die begrip mettertyd tot 'n kulturele en politieke inhoud uitgebrei. In die tyd van die Nuwe Testament het dié begrip, naamlik bewoonde aarde, op die 
beskawing van die Romeinse Ryk gedui - in teenstelling met die onbeskaafde wêreld (Nijenhuis, 1959:3). lets van menslike gemeenskaplikheid, om nog nie te sê volstrekte eenheid nie, kon reeds uit dié term afgelei word. Mettertyd is die oorspronklike geografiese inhoud van die begrip tot 'n kulturele en politieke inhoud uitgebrei, veral ten opsigte van die hellenistiese kultuurwêreld.

Jesus het 'n volkome nuwe perspektief aan die konsep oikoumené gegee deur die gerigtheid daarvan op die Romeinse Ryk te verplaas na "al die nasies" wat die getuienis sal hoor (Matt. 24:14). Die verkondiging van die evangelie aan "al die nasies" in die "hele wêreld" (oikoumené) stuur op die einde af. In hierdie betekenis dui oikoumené in die Nuwe Testament ook op die "toekomstige wêreld" (Hebr. 2:5) waarin die eenheid van die nasies in Christus tot voltooiing kom. Die Nuwe-Testamentiese ontwikkeling van die woord bied dus ' $n$ duidelike perspektief op die gelowiges wat vir 'n nuwe wêreld bestem is. Sodoende word die kerk, as die beliggaming van dit wat blywend is, al hoe meer gekontrasteer met die verbygaande wêreld.

Mettertyd het die betekenislading van die konsep verder ontwikkel en op die kerk in sy katolieke, universele bestaan begin dui. Ook waar kerklike konsilies as die geldige verteenwoordiging van die ganse kerk aanvaar is, het die begrip ekumenisiteit na vore gekom. Die woord is vir die eerste keer in hierdie betekenis gebruik in 381 n.C. toe die Konsilie van Konstantinopel verwys het na die "ekumeniese" sinode van Nicea wat in 325 n.C. gehou is. Hierna is die Konsilies van Konstantinopel (381 n.C.), Efese (431 n.C.) en Chalcedon (451 n.C.) ook as ekumenies beskou, omdat hulle as verteenwoordigend van die universele kerk geag is (Bronkhorst, 1960:243; Nijenhuis, 1959:3; Goosen, 1993:10).

Uiteindelik is die woord ekumenisiteit gebruik om die wêreldwye geloofsverhoudings van individuele gelowiges en kerkgemeenskappe oor die grense van denominasies en lande aan te dui. In die negentiende en twintigste eeu word gepraat van die "ekumeniese sendingopdrag", met die betekenis van die wêreldwye sendingopdrag van die kerk. Tegelyk slaan die betekenis van ekumenisiteit ook op aktiwiteite wat die wêreldwye "saamhoort" van die kerk van Christus tot uitdrukking wil bring. In 1929 word sowel die Duitse as die Franse benaming van die Universal Christian Council for Life and Work verander na Oekumenischer Rat (Conseil Oecuménique). Sedert die Oxfordberaad in 1937 is hierdie term ook in die Engelse wêreld geyk (Bronkhorst, 1960:243; Nijenhuis, 1959:3; Goosen, 1993:11). 
Pelser (1976:344) laat hom byvoorbeeld só uit oor die ekumene:

Die ekumene is die arbeidsveld van die kerk; dis die ruimte waarin die kerk lewe, waarin hy die koningskap van Christus proklameer en wat hy opeis vir Hom wat in Hebr. 1:6 die eersgeborene van die oikumené genoem word.

Vanaf die tweede helfte van die vorige eeu word die kerk se roeping tot universele eenheid al hoe meer deur die term ekumenisiteit tot uitdrukking gebring, teen die agtergrond van die feitelike situasie van die kerk se verskeurdheid in die wêreld. Snyman (1977:85) het hierdie roeping in die sestigerjare van die vorige eeu soos volg gesien:

- die bewaring en beskerming van kerkeenheid waar dit bestaan, ook oor landsgrense;

- samesprekings om kerkeenheid te herstel waar dit nie bestaan nie; en

- die roeping tot samewerking in soverre daar ooreenstemming is.

Die verskeurdheid van die kerk kom al van sy vroegste bestaansjare af na vore, soos die sondeverskeurdheid van die mens wat van sý vroegste bestaansjare af na vore gekom het. Hierop wys Paulus in die Nuwe Testament skerp afwysend: "Is Christus dan in stukke verdeel?" (1 Kor. 1:13; vgl. Calvyn, 1992, Inst. 4.13.14.).

Calvyn (1972:21-24) spreek hom uit oor die onhoudbaarheid van die verskeurdheid van die kerk:

Die kerk word daarom katolieke of algemene kerk genoem omdat daar nie twee of drie kerke kan bestaan sonder dat Christus verskeur word nie - en dit kan tog nie gebeur nie! ... Hoewel die droewige verwoesting waarvoor ons oral te staan kom, dus uitroep dat daar niks meer van die kerk oor is nie, weet ons dat Christus se sterwe vrug dra en dat God sy kerk wonderbaarlik bewaar asof dit in 'n skuilplek is.

Calvyn (1972:21-24; vgl. Calvyn, 1992, Inst. 4.1.2; 4.1.10; 4.1.15; 4.1.18; 4.1.19) sê dat daar niks méér vreemds aan die Christelike geloof is nie as dat een gelowige homself van ander gelowiges afskei "en derhalwe die middelpunt van die Christelike geloof aanval en verlaat". Hierdie uitgangspunt van Calvyn moet as die grondslag van al sy ekumeniese handelinge gesien word (Nijenhuis, 1959: 277). 
Berkouwer $(1976: 43,77)$ voer aan dat die meervoudige "kerkgemeenskappe"-verskynsel ewe ondenkbaar is as 'n meervoudige konsep van "volke van God" in die Ou Testament. Tog staan ons voor die onvermydelike "nog nie" van die sonde-verskeurde werklikheid waarin kerkeenheid reeds kragtens die wese van die kerk teenwoordig is, maar "nog nie" ten volle nie (vgl. Berkouwer, 1976: 40).

Die bekende teoloog Hans Küng (1978:303), sê:

As die kerk een is, moet dit universeel wees; en as die kerk universeel is, moet dit een wees. Eenheid en katolisiteit is twee interverweefde dimensies van een en dieselfde kerk.

Samevattend kan gesê word dat die begrip ekumenisiteit ook 'n geestelike houding verteenwoordig - 'n houding waardeur die dringende bewustheid van en die verlange na die eenheid van die kerk van Christus vergestalt word. So het die "ekumeniese beweging" die wêreldwye proses vir 'n groter uitdrukking van eenheid en samewerking onder alle Christene geword (vgl. Smit, 2006:92-93).

\section{Die GKSA se ekumeniese gerigtheid deur die eerste halfeeu (1859-1909)}

Vanaf die eerste sinode van die GKSA in 1862 is ekumenisiteit as 'n dringende roeping beskou. In die "Voorbericht" van die Handelinge van dié sinode word verklaar:

Geliefde Broeders en Zusters, in den Heere! die met ons deelen in hetzelfde geloof - in Afrika, Europa, en Amerika - ja, waar ter wêreld dit ook moge komen, onder het oog desgenen, die met ons even dierbaar geloof verkregen heeft, door de groote genade onzes getrouwen Verbonds-God ... naardien wij met die Gereformeerde Christenen in dezelve, niet alleen ons dankbaar en opgewekt vereenigd gevoelen, om ook met hen, de banier der waarheid hooge op te heffen, in den naam des Heeren, tegenover de dwaling dezer dagen: maar ook met dezelve, door woning of afkomst, naauw vereenigd zijn. (GKSA, 1862:3.)

Op dieselfde sinode (1862) gee die GKSA in 'n openlike verklaring (wat sedertdien op elke meerdere vergadering voorgehou word) te kenne:

Allen, die met haar even dierbaar geloof verkregen hebben, door de genade des $\mathrm{H}$. Geestes, en - ditzelfde met haar wenschen te belijden en te betrachten, noodigt zij hartelijk, tot 
hare Kerkgemeenschap uit, en wenscht met alle Kerken, in dit Wêrelddeel en in andere landen, ditzelfde met haar belijden en betrachten, de innigste broederlijke gemeenschap in correspondentie te onderhouden. (GKSA, 1862:8.)

Die term wat gebruik word om uitdrukking aan kerklike eenheid te gee, korrespondensie, kom reeds in die Dordtse Kerkorde van 1618/1619 in artikels 48 en 52 voor as "'n tussenkerklike handeling om kerklike eenheid te behou en te beoefen" (Kersten, 1961:186, 187). Hierdie term het in die gereformeerde kerkreg die betekeniswaarde van eenheid in leer, diens en tug - in werklikheid word niks minder nie as kerkverband tussen verskillende kerkgemeenskappe (ook oor landsgrense heen) hierdeur tot uitdrukking gebring.

Terselfdertyd verklaar die sinode van 1862 homself verplig om 'steeds in de vriendelijkste broederlijke correspondentie te deelen met die Christelijk Afgescheidene Gereformeerde Kerk in Nederland' met wie die sinode hom nie slegs 'het naauwst verbonden' voel nie: 'maar acht zich met haar één te zijn' (GKSA, 1862, art. 30:13). Daar is ook besluit om eksemplare van die Handelinge van hierdie eerste sinode na die 'Nederduitsch-Gereformeerde Kerk' te stuur (GKSA, 1862, art. 32:17), aan die 'Christelijk Afgescheidene Gereformeerde Kerk in Nederland', aan die 'Vrije Schotsche Kerk in Skotland', en aan 'de Kerk in Noord-Amerika, welke zich noemt: The Dutch Reformed Church ... opdat de band der zamenbinding, naauwer worde toegehaald' (GKSA, 1862, art. 41:19).

Ook tydens die sinodes van 1866 (kyk GKSA, 1866, art. 50:14) en 1873 (GKSA, 1873:3) word die eenheid met gereformeerde kerke elders in die wêreld, en die uitreiking na hierdie kerke, uitdruklik vermeld. Tydens laasgenoemde sinode word die belewenis van die katolisiteit van die kerk soos volg in die Voorbericht van die Handelinge uitgedruk:

Dat wij de vrijheid nemen onze broeders en zusters in de drie werelddeelen aan te spreken, gelijk ook bij onze eerste Synode, is, omdat de Zusterskerken uit de drie werelddeelen op onze Synode vertegenwoordigd werden; ... en wij ons ook door afkomst naauw en door het geloof geheel vereenigd gevoelen met de Gereformeerde Christenen in die drie werelddeelen, in leer, dienst en tucht. (GKSA, 1873:3.)

Op die sinode van 1873 word spesifiek reëlings getref vir korrespondensie met die Christelike Gereformeerde Kerk in Nederland (GKSA, 1873, art. 143:39; vgl. ook GKSA,1873, art. 122:34; 1876, art. 241:64). Die sinode van 1876 besluit ook om op uitnodiging 
(GKSA, 1876, art. 31:14) 'n skrywe te rig aan die "algemeen presbyteriaansche concilie" wat in Julie 1877 in Edinburg, Skotland gehou word (GKSA, 1876, art. 242:65). Die sinode van 1879 (GKSA,1879, art. 50:23) neem 'n uitnodiging ter tafel van "de Synodale Commissie der Ware Hollandsch Gereformeerde Kerk in Noord-Amerika" om 'n afvaardiging na hierdie kerkgemeenskap se volgende "algemeene vergadering" te stuur - waarop vanweë afstand en koste 'n wederuitnodiging gerig word om "de Kerk alhier eens te bezoeken", omdat "deze Synode ernstig verlangt" dat so 'n besoek moet plaasvind. 'n Soortgelyke uitnodiging van die Christelike Gereformeerde Kerk in Nederland word ook vanweë die omstandighede van die hand gewys (GKSA, 1879, art. 88:31).

Die lyn van voortgesette korrespondensie met gereformeerde kerkgemeenskappe blyk tot aan die einde van die eerste halfeeu (GKSA, 1904, art. 106:32; 133:40; 134:41; 213:66, 67; 219:68).

\section{Die GKSA se ekumeniese gerigtheid deur die tweede halfeeu (1909-1959)}

Deur die eerste dekades van die tweede halfeeu van die GKSA word die lyn van voortgesette korrespondensie gehandhaaf (GKSA, 1913, art. 13:11; 1916, art. 182:58; 1920, art. 108:50; 1924, art. 184:63). Mettertyd brei die gerigtheid op korrespondensie met buitelandse kerkgemeenskappe uit, deurdat die Gereformeerde Kerke van Duitsland en Hongarye by die van Nederland en Amerika gevoeg word (GKSA, 1927, Bylae K:146; vgl. art. 124:45).

Ook die binnelandse ekumenisiteit ten opsigte van gereformeerde kerkgemeenskappe ontwikkel in 'n beduidende rigting. In 1936 besluit die GKSA om saam te werk aan die totstandkoming van 'n Tussenkerklike Kommissie (TKK) tussen die GKSA, die NGKSA en die NHKSA, waardeur die verhinderings van eenheid tussen dié kerkgemeenskappe in samewerking met mekaar opgelos moet word (GKSA, 1936:37). Tegelyk bied die TKK 'n samewerkingsmeganisme waardeur die betrokke kerkgemeenskappe gemeenskaplike sake, veral in die breër samelewing, deur die komende dekades gemeenskaplik sou hanteer.

Vanaf 1949 het die sinodes van die GKSA die volgende onderskeid gemaak:

Kerklike korrespondensie in enger sin wat gelykstaan aan kerkverband oor nasionale grense, en 
Kerklike korrespondensie in wyer sin wat nie kerkverband inhou nie, en wat onderhou word met kerke binne en buite die nasionale grense. (GKSA, 1979, 3.1.4.2:41.)

Die sinode van 1952 gebruik die term offisiële korrespondensie in plaas van korrespondensie in enger sin. Waar korrespondensie in enger sin in voorbereiding is, word van kerklike kontak gepraat (GKSA, 1952:235 e.v.).

In 1955 word die term kerklike korrespondensie, in die betekenis van deurlopende kerklike kontak, verder amptelik gehandhaaf (GKSA, 1955:163, C(1)). Terselfdertyd word teruggekeer na die onderskeiding in hierdie begrip, naamlik korrespondensie in enger sin, wat één kerkverband beteken, en korrespondensie in ruimer sin, wat onderhandelings en samewerking op bepaalde vlakke op pad na één kerkverband beteken (GKSA, 1955, C(3):163).

Tog het die behoefte reeds bestaan dat die begrip korrespondensie duideliker gedefinieer word: "Die term korrespondensie hoef nie vervang te word deur 'n ander term wat beter sal pas by die huidige omstandighede nie, maar dit moet slegs nader omskryf word." (GKSA, 1955, C(1):163.)

Die sinodes van 1955 (GKSA, 1955:298) en 1958 (GKSA, 1958:68) wys, kennelik met die oog op die kerkverdeeldheid onder gereformeerdes in Nederland, korrespondensie met meer as een kerk in dieselfde land af. Die motivering was dat eenheid nie onderhou kan word met twee kerkgemeenskappe in dieselfde land wat nie onderlinge eenheid beoefen nie.

Dat die "korrespondensie" met buitelandse gereformeerde kerkgemeenskappe intussen al hoe meer inhoudelike betekenis verkry, blyk uit verskeie adviesvrae van Nederlandse kerkgemeenskappe oor besluite van die GKSA, byvoorbeeld in verband met vrouestemreg in die kerk, die binding van die gemeentestem op die kerkraad, ensovoorts (GKSA, 1930:4). Steeds word bande met buitelandse kerkgemeenskappe uitgebrei en verdiep, mede deur oor en weer uitnodigings na sinodesittings en die beantwoording van adviesvrae (GKSA, 1933, art. 22:22-24).

Die ideaal van 'n Gereformeerde Ekumeniese Sinode (GES) leef dermate in die GKSA dat die GKSA se afgevaardigdes hierdie konsep op die sinode van die Gereformeerde Kerke in Nederland (GKN) in 1936 opper (GKSA, 1939:149). Hierdie konsep kry verdere beslag op die sinode van 1942 in die rapport van die afgevaardigdes na die sinode van 1939 van die GKN te Sneek (GKSA, 1942:89-91) asook 
op die GKSA-sinodes van 1945 en 1946 (GKSA, 1945:176-179; 1946:25-32).

Die eerste ekumeniese sinode is in 1949 te Grand Rapids gehou, waar afgevaardigdes van die GKSA, die GKN en die CRCNA byeengekom het (GKSA, 1949:24-38). Hierdie kerkgemeenskappe kan derhalwe as die stigterslede van die toenmalige GES beskou word, met die GKSA as die inisieerder daarvan. Vir die volgende dekades het die GES 'n deur vir die GKSA na ander gereformeerde kerkgemeenskappe in die wêreld oopgemaak vir besluitneming oor kwessies soos korrespondensie, ekumenisiteit, die vrou in die amp en rasseverhoudings in die kerk (GKSA, 1952:235-238; 1955:157-166). In 1958 ontvang die GKSA die ekumeniese sinode op Potchefstroom (GKSA, 1958:48).

Die dwingende eis van die eenheid van die universele kerk van Christus word deur die GKSA op die sinode van 1958 soos volg verwoord:

Die veelheid van kerke word aanvaar, maar nie om daarby te berus nie ... Die eenheid van die kerk as mistieke liggaam van Christus is 'n werklikheid, maar die eenheid van die uitwendige kerk is goddelike eis en opdrag. Hieruit vloei die roeping van die kerk voort om dit wat uitmekaar hou, broederlik met mekaar onder oë te sien om sodoende te bring in een kerkverband. (GKSA, 1958:79.)

\section{Die GKSA se ekumeniese gerigtheid deur die derde halfeeu (1959-2009)}

Tydens die eeufees van die GKSA in 1959 is van buite die landsgrense groeteboodskappe ontvang, naamlik van die Gereformeerde Kerke in Nederland, die Christian Reformed Church in North America, die Gereformeerde Kerk Dokkum, (Nederland), die Orthodox Presbyterian Church in America en die Christelijke Gereformeerde Kerk in Nederland - kerkgemeenskappe waarmee die GKSA in noue verbondenheid, te wete "korrespondensie", op ekumeniese vlak omgegaan het (vgl. Du Toit, 1959:108-121). Dit is interessant dat die Gereformeerde Kerk Dokkum, die kerk wat die eerste predikant uit Nederland gestuur het wat deur die Gereformeerde Kerk Rustenburg beroep is, naamlik ds. Dirk Postma, spesifiek ook 'n groeteboodskap gelewer het.

Van binne die landsgrense is groeteboodskappe ontvang van die Nederduitse Gereformeerde Kerk in Suid-Afrika, die Nederduitsch 
Hervormde Kerk in Suid-Afrika, die Nederduitse Gereformeerde Kerk in Suidwes-Afrika, die Church of England in South Africa en die Presbyterian Church of South Africa. Hieruit blyk dat ekumeniese kontak met gereformeerde kerkgemeenskappe binne die landsgrense ook verder ontwikkel het (vgl. Du Toit, 1959:74-84).

Die GKSA se prioriteit ten opsigte van kerkeenheid, ook met buitelandse gereformeerde kerkgemeenskappe, kom daarin tot uitdrukking dat nasionale sinodes van die GKSA telkens deputate vir "Ekumeniese Sake", kragtens Kerkorde art. 49, 'n mandaat verleen "om deurlopend kontak te maak met gereformeerde buitelandse kerkgemeenskappe oor sake van dringende en gemeenskaplike belang", maar veral "ter wille van die eenheid van die kerk van Jesus Christus" (GKSA, 1967:366; 1997:176, 178).

Die behoefte aan nadere omskrywing van die begrip korrespondensie het egter steeds aktueel gebly, en die versugting van 1955 word in 1961 herhaal: "Vir die toekoms, ook in ons eie land, moet daarmee rekening gehou word dat kerklike korrespondensie steeds nader omskryf moet word, na die eis van omstandighede." (GKSA, 1961, C: 528.)

Die ontwikkeling in die denke oor die begrip korrespondensie lei daartoe dat daar twee lyne bestaan. Daar is die ekumeniese lyn wat op 'n "volwaardige ekumeniese sinode" volgens KO art. 29 moet uitloop (GKSA, 1970:80; 1979:46), en wat as hegte ekumene beskou moet word. Daarteenoor, kan ook 'n lyn van losser ekumene gekonstateer word (GKSA, 1997:170). Onder laasgenoemde kategorie word byvoorbeeld ekumeniese bewegings ingesluit waarin kerkgemeenskappe verteenwoordig word (GKSA, 1970:88). In hierdie "losser samevoeging" van kerkgemeenskappe is aansluiting uitgesluit (GKSA, 1967:367), maar "een of ander vorm van kontak" word kragtens KO art. 49 as gewens beoordeel (GKSA, 1967:367; 1970:89).

Die GKSA kom ook tot die oortuiging dat onderskei moet word tussen die roeping tot belewing van eenheid (kerke wat één in leer, diens en tug is), wat begrens is, en die onbegrensde roeping tot ekumenisiteit. Laasgenoemde roeping gaan tot alle kerke uit in oproep tot gehoorsaamheid aan die Woord van God en tot die onderlinge gemeenskap van gelowiges (GKSA, 1967:366).

Teenoor die sinode van 1955 (GKSA, 1955:298) en die sinode van 1958 (GKSA, 1958:68), en anders as die Gereformeerde Kerken 
(Vrijgemaakt) in Nederland, ontwikkel die sinode van 1961 (GKSA, 1961:526, 534) die insig

... dat gelyktydige korrespondensie ... met kerke oor die nasionale grense wat in verskillende kerkverband is, en waarmee daar eenheid in leer, diens en tug bestaan, onderhou kan word. Hierdie moontlikheid word geskep deurdat die verdeling en skeiding van kerke wat in een land voorkom, nog glad nie die kerke in ander lande in daardie geskilpunte betrek nie, omdat hulle in wese nog oopstaan ten opsigte van die sake wat die gemoedere elders verdeel. (GKSA, 1961:528, 529; vgl. 1979:41.)

Hierdie "dubbelkorrespondensie" word deur die sinode van 1979 verder gemotiveer. "Vanweë die realiteit van die onvolkomenheid en gebrokenheid van die strydende kerk kan korrespondensie nodig wees met meer as een kerk(verband) in dieselfde land." (GKSA, 1979:46, 2.)

Die GKSA se siening van ekumenisiteit het steeds ruimer ontwikkel. Ook met kerkgemeenskappe wat op die gereformeerde belydenis staan, kan saamgewerk word, deurdat dié kerkgemeenskappe die GKSA se volle erkenning as medekerk van Christus ontvang. Die sinode van 1964 onderskei tussen kerke in verskeidenheid en in geskeidenheid. "Met die eerste is daar en moet daar wees kerkverband, met die tweede samespreking en/of samewerking. Samewerking vereis reeds samestemming oor belangrike punte van die Konfessie en kerkregering." (GKSA, 1979, 3.1.4.3:42.)

'n Verdere insig, wat kennelik teen stagnasie stry en bereidwilligheid toon om self te reformeer waar die Skrif dit vereis, ontwikkel sedert 1967 waar dié sinode ekumeniese gesprek definieer as "geen eensydige monoloog nie, daar moet getuienis en selfondersoek wees ... onderwerping aan die Skrif as uitgangspunt ... die doel is herstel van gemeenskap langs die weg van reformasie op grond van God se Woord" (GKSA, 1979, 3.1.4.4:42). 'n Uitdrukking daarvan dat die GKSA nie die waarheid slegs in sy eie siening van die belydenis en in sy eie interpretasie van die Skrif probeer vind nie, lê in die besluit van die sinode van 1979. Hiervolgens stel die GKSA hom oop om in wisselwerking met ander Gereformeerde kerkgemeenskappe, waar dit nodig mag wees, steeds self op grond van die gereformeerde belydenis te reformeer (GKSA, 1979:42).

Die sinode van 1979 besluit dat die onderskeid tussen enger en ruimer korrespondensie moet verval (GKSA, 1979, art. 4.1.3.1:45). Slegs die term korrespondensie word gehandhaaf en wel in die be- 
tekenis van eenheid in leer, diens en tug, dit wil sê in die betekenis van kerkverband (GKSA, 1979, 4.1.1:45). Hiervolgens moet kerkverband ooreenkomstig $\mathrm{KO}$ art. 51 en die belydenis van die algemeenheid (katolisiteit) van die kerk geïnstitueer word tot op ekumeniese vlak in 'n volwaardige ekumeniese sinode "ter behoud en beoefening van die eenheid in leer, diens en tug" (GKSA, 1979, 4.1.2:45).

Die term kerklike gemeenskap word afgewys vir die beskrywing van kerklike verhoudings waar eenheid in leer, diens en tug nie bestaan nie, "aangesien die Bybelse begrip 'gemeenskap' die eenheid impliseer" (GKSA, 1979, 4.1.3.2:45). Kerklike verhoudings wat nie onder korrespondensie val nie, word op meriete in elke individuele geval vasgestel "soos dit nodig word" (GKSA, 1979, 4.1.3.4:45).

'n Belangrike insig wat ook ontwikkel, is dat met die eenheid van die kerk as liggaam van Christus nie eendersheid van plaaslike kerke of kerkstrukture bedoel word nie. Hierin word binne kerkeenheid die ruimte erken vir uitwendige verskille, byvoorbeeld in liturgie en bedieningsmetodes, wat tussen plaaslike kerke in verskillende wêrelddele voorkom en as sodanig gerespekteer moet word (GKSA, 1997, 2.1.1.4:171). In werklikheid gaan dit reeds hier om diversiteit wat na eenheid strewe en eenheid wat diversiteit behou.

\section{Die GKSA se formulering van die doel van ekumenisiteit}

In 1970 verklaar die GKSA (1970:69) dat die doel van die deputate se opdrag bly om die eenheid van die kerk wêreldwyd as "ons dringendste en belangrikste ekumeniese roeping" te sien. Hierdie doel word nagestreef, sê die sinode van 1979, deur in die ekumeniese gesprek die universele evangelie uit te dra om alle kerke "tot gehoorsaamheid aan die Woord van God en so tot kerklike gemeenskap op grond van ooreenstemming van die leer" op te roep (GKSA, 1970:69).

Die doel van die ekumeniese gesprek is

... die uitdra van die universele evangelie waardeur alle kerke onder alle volksgroepe ... tot gehoorsaamheid aan die Woord van God en so tot een kerklike gemeenskap op grond van ooreenstemming van die leer ... opgeroep word (GKSA, 1994, 2.2.1.1:195; vgl. 1967:366).

Die ekumeniese roeping is dan gerig op 'herstel van die eenheid van die kerk', [want] geskeidenheid van kerke is 'n sondige 
verskynsel ...', en 'met sonde kan daar nie vrede wees nie'. (GKSA, 1967:365.)

Dit is die taak van die Kerk om die eenheid in die Here te soek waar dit nog ontbreek of te herstel waar dit verbreek is. Dit kan alleen deur getuienis van die waarheid en gevolglike reformasie in gehoorsaamheid aan die Skrif. (GKSA, 1979, 3.3.8:45.)

Ekumenisiteit (katolisiteit - art. 27 NGB) is die wêreldwye onbegrensdheid ('verspreid en verstrooid oor die hele wêreld') van die ware gelowiges, d.w.s. die eenheid van die kerke oor nasionale grense heen. (GKSA, 1979, 4.3.1:46.)

Die ekumeniese roeping is die opdrag van die Here om met kerke wat buite die ekumeniese kerkverband staan eenheid te soek deur samespreking oor verskille en samewerking in sover ooreenstemming dit reeds toelaat. (GKSA, 1979, 4.3.2:46.)

\section{Die GKSA se siening van ekumenisiteit in konsentriese sirkels}

Uit die ontwikkeling van ekumenisiteit in die GKSA, soos hierbo uiteengesit, het dit duidelik geword dat die term korrespondensie, sonder nadere omskrywing daarvan, ontoereikend is om die veelduidige en dinamiese proses van ekumeniese onderhandelings te omskryf. Hierdie proses beweeg as 't ware in konsentriese sirkels van periodieke kerklike kontak na kerklike verhoudings tot by kerklike eenheid. Tog is dit noodsaaklik om in begrippe en in terminologie te onderskei tussen die onderskeie fases van ekumeniese handelinge, byvoorbeeld dié wat op samewerking afgestem is met die langtermyn moontlikheid van kerklike eenheid en dié in voorbereiding tot kerklike eenheid. Daarom het die sinodes van 2000 en 2003 dit noodsaaklik geag om in ooreenstemming met vorige sinodebesluite 'n duidelike formulering van die begrip korrespondensie te gee. Hierdie formulering bring ekumenisiteit in sy onderskeidende konsentriese fases van ekumeniese kontak, ekumeniese bande en ekumeniese eenheid tot uitdrukking. Die proses op pad na ekumeniese eenheid, oftewel 'n kerkregtelik verantwoorde vorm van kerkverband tussen verskillende kerkgemeenskappe, is nie staties nie, maar beweeglik en dinamies. Die onderskeie fases moet dus nie as waterdigte kategorieë gesien word nie. Daarom word die genoemde drie fases as 'n beweging in konsentriese sirkels weergegee.

Die sinode van 2003 (GKSA, 2003:174) omskryf die aard van ekumenisiteit in sy verskillende fases op grond van die formulering van die sinode van 2000 (GKSA, 2000:210) soos volg: 
In die binneste sirkel, waar korrespondensie (eenheid in kerkverband) uitgedruk word, praat ons van ekumeniese eenheid.

In die tweede sirkel, waar gesprekke en samewerking uit roepingsvervulling van die een kerkgemeenskap teenoor ' $n$ ander in koninkryksgerigtheid plaasvind, ook ter voorbereiding van een kerkverband, praat ons van ekumeniese bande.

In die derde en wydste sirkel, waar gesprekke en samewerking plaasvind met die doel van die uitbreiding van die koninkryk (gesamentlike optrede en profetiese getuienis) en met die langtermyn doel van een kerkverband, praat ons van ekumeniese kontak.

\subsection{Die binneste sirkel: ekumeniese eenheid}

In die binneste sirkel onderhou die GKSA tans ekumeniese eenheid met veertien kerkgemeenskappe wêreldwyd. Die sinode van 2003 het dit goedgekeur dat die Deputate vir Ekumenisiteit: Buitelands dit as hulle mikpunt stel om ten minste elke drie jaar samesprekings te hou met soortgelyke deputate van die kerkgemeenskappe met wie die GKSA oor plaaslike en internasionale kerklike sake in korrespondensie is. Sodoende kan aan elke sinode gerapporteer word oor die stand (en voortsetting) van ekumeniese eenheid met dié kerkgemeenskappe met wie die GKSA korrespondensie onderhou (GKSA, 2003, 2.17:215).

Kerklike korrespondensie hou in dat attestate oor en weer erken word, beroeping van predikante kan oor en weer plaasvind en insette tot besluitvorming oor en weer by wyse van afgevaardigdes op mekaar se sinodes gegee word. Om verdere inhoud aan hierdie eenheidsband te gee, word die betrokke kerkgemeenskappe op hoogte gehou van sinodebesluite; deputate van die GKSA verkry ook van buitelandse kerkgemeenskappe-in-korrespondensie hulle insette vir rapporte op verskillende gebiede, waar dit van toepassing is, wat dan aan die sinode voorgehou word. Hierdie kerkgemeenskappe sluit die volgende in: die Christelijke Gereformeerde Kerken in Nederland, die Christian Reformed Churches in North America, die Free Church of Scotland, Die Presbyterian Church in Korea, die Reformed Church in Japan, die Nederlands Gereformeerde Kerken, die Christian Reformed Churches of Australia, die Reformed Churches of New Zealand, die Reformed Church of Botswana, die Reformed Churches in Zaïre (Eglise Reformee Confessante au Congo), die Free Church of Scotland (Continuing), die Orthodox Presbyterian Church of North America, die Gerefor- 
meerde Kerken in Nederland (Vrijgemaakt) en die Reformed Church of Kenya (Smit, 2009:144).

\subsection{Die tweede (middelste) sirkel: ekumeniese bande}

Vanuit die middelste sirkel is die deputate met verskillende kerkgemeenskappe wêreldwyd in gesprek, waar samewerking uit roepingsvervulling van die een kerkgemeenskap teenoor 'n ander in koninkryksgerigtheid plaasvind, met die oog op vordering na ekumeniese eenheid (GKSA, 2006:194 e.v.). In die binnesentrum van hierdie fase word die gesprek met die Vrye Gereformeerde Kerke in SuidAfrika (VGKSA), die NG Kerk, Hervormde Kerk en die APK voortgesit. Na langer as 'n halwe eeu se samesprekings tussen die GKSA, die NG Kerk en die Hervormde Kerk het die deputate van hierdie onderskeie kerkgemeenskappe tot die gevolgtrekking gekom dat daar nog onopgeloste verskille is, byvoorbeeld oor kerklike etos, kerkbegrip, interpretasie van die belydenisskrifte, en in 'n mate ook oor Skrifbeskouing. Daarom is erkenning daaraan gegee dat die ideaal van strukturele eenheid nie in die afsienbare toekoms bereik sal kan word nie. Hierdie kerkgemeenskappe het besluit dat dit in die lig van soveel vlakke van geloofs- en kerkooreenkomste onverantwoordelik sou wees om in kokonne langs mekaar te bestaan sonder om enige kerklike erkenning aan mekaar te gee. Die historiese- en belydenisband, waarin op 'n eiesoortige wyse 'n bepaalde vorm van eenheid ontwikkel het, is daarom in 2004 op 'n eiesoortige manier tot uitdrukking gebring. Die Tussenkerklike Kommissie (TKK) is omvorm tot 'n Tussenkerklike Raad (TKR) waarin samewerking op verskeie vlakke kerkregtelik verankerd voortgesit en uitgebou word (Smit, 2009:144; vgl. TKR, 2004).

\subsubsection{Tussenkerklike Raad}

Die TKR het in 2004 tot stand gekom en funksioneer as 'n tussenkerkgemeenskaplike meerdere vergadering wat sy opdrag van die onderskeie sinodes ontvang en aan hulle rapporteer.

In die Grondslag van die Tussenkerklike Raad stel die "Historiese Perspektief" die volgende:

Die samestellende kerke tydens stigting is die Gereformeerde Kerke in Suid-Afrika, die Nederduitse Gereformeerde Kerk en die Nederduitsch Hervormde Kerk van Afrika. Die besondere verhouding tussen hierdie kerkgemeenskappe, wat vanaf 1958 in die Tussenkerklike Kommissie tot uitdrukking gekom het, het in Februarie 2004 op die stigting van die Tussenkerklike Raad uitgeloop. Hierdie verhouding het uit 'n gemeenskaplike Refor- 
matoriese herkoms, 'n gesamentlike sosio-historiese kontekstualiteit en 'n gemeenskaplike taal gegroei. Ondanks die verskeidenheid in kerkformasie en kerklike etos, asook graadverskille in die belewing van die gemeenskaplike belydenis, het dié kerkgemeenskappe deur die jare op grond van 'n gemeenskaplike groeibodem 'n verhouding van geloofseenheid in Christus gehandhaaf en hulle streef steeds daarna om dié verhouding tot 'n hegter kerkregtelik verantwoorde eenheid te voer. (Smit, 2009:144; TKR, 2004:1.)

Die saamwerkende kerkgemeenskappe stel die Tussenkerklike Raad saam op 'n wyse wat elke kerkgemeenskap geskik ag. Die verteenwoordigers van die saamwerkende kerkgemeenskappe werk op sterkte van die mandaat wat die betrokke kerkgemeenskap aan hulle verteenwoordigers gegee het in die Tussenkerklike Raad saam binne die raamwerk van die Skrif, die Drie Formuliere van Eenheid en die betrokke kerkorde van elke kerkgemeenskap. Binne hierdie raamwerk oordeel die Tussenkerklike Raad hoe die agenda afgehandel kan word en rapporteer aan die onderskeie kerkgemeenskappe oor sy werksaamhede.

Die doelstellings van die Tussenkerklike Raad word volgens die $T K R$ Grondslag in die volgende opdrag geformuleer:

Om kerklike eenheid op grond van dieselfde belydenisskrifte in Jesus Christus te belewe en te bevorder deur

- 'n krities-opbouende gesprek tussen die saamwerkende kerkgemeenskappe voort te sit;

- kennis te neem van bestaande samewerkingsterreine en 'n geheelbeeld daarvan aan die saamwerkende kerkgemeenskappe te gee;

- nuwe samewerkingsterreine tussen die saamwerkende kerkgemeenskappe te identifiseer, te koördineer, en met verantwoording aan die onderskeie mandaatgewers uit te bou;

- waar nodig gesamentlike getuienis in die samelewing en aan die owerhede te lewer;

- in die Tussenkerklike Raad nuwe ontwikkelinge in die saamwerkende kerke, of beëindiging van bepaalde kerklike praktyke, of verdere presisering van wesenlike aspekte van kerkwees in die ontwikkelingsfase daarvan mee te deel en te toets; 
- kerklike sake van gemeenskaplike belang gesamentlik in 'n wyer sfeer in die Konvent van Reformatoriese Kerke in Suider-Afrika te bevorder. (Smit, 2009:145; TKR, 2004:1, 2.)

Bestaande samewerkingsterreine is onder meer reeds gevestig in die volgende:

- Bybelvertaling;

- dae van verootmoediging en gebed;

- vertalings, wysigings en samestellings van liturgiese en ander kerklike geskrifte;

- gesamentlike kerklike belange in onderwys- en maatskaplike sake;

- gesamentlike projekte in die breë gemeenskap; en

- samewerking tussen kerkgemeenskappe op plaaslike vlak (Smit, 2009:145; TKR, 2004:1, 2).

Volgens die TKR Grondslag word die mandaatgewende vergaderings versoek dat die betrokke saamwerkende kommissies en deputategroepe jaarliks inligting van hulle werksaamhede aan die Tussenkerklike Raad sal verskaf met die oog op 'n geheelbeeld, die identifisering van bykomende sake, en die ontginning van nuwe samewerkingsterreine. Hierdie deputaatgroepe en kommissies van die onderskeie kerkgemeenskappe rapporteer steeds aan hulle mandaatgewers (Smit, 2009:145).

\subsubsection{Konvent van Reformatoriese Kerke in Suider-Afrika}

'n Verdere ontwikkeling op die vlak van die middelste sirkel het in 1998 tot stand gekom. Uit 'n diepgevoelde behoefte dat gereformeerde kerke op die een of ander manier met mekaar moet skakel, is die Konvent van reformatoriese Kerke in Suider-Afrika tot stand gebring. Navrae en samesprekings het laat blyk dat daar in SuiderAfrika nie slegs vier (Afrikaanse) kerkgemeenskappe is wat uit die gereformeerde tradisie stam nie, maar tussen twintig en dertig (vanselfsprekend ook nie-Afrikaanse kerke). Die Konvent het tot stand gekom, nie om te poog om één kerkverband daar te stel nie, maar om ' $n$ forum te bied vir kerke van dieselfde landstreek en uit dieselfde reformatoriese erfenis om saam te praat, saam te dink, mekaar te help, en teenoor die owerheid en in die gemeenskap 'n gereformeerde stem te laat hoor. Tans is daar dertien kerkgemeenskappe en kerkgroepe wat in die Konvent met mekaar skakel. 
Hieruit het ook reeds onderlinge twee- en driegesprekke tussen kerkgemeenskappe ontwikkel. Die herdenking van die tiende bestaansjaar van die Konvent het in 2008 op Potchefstroom plaasgevind (GFK, 2008:i-v).

In die Grondslag en Funksionering van die Konvent van Reformatoriese Kerke in Suider-Afrika (GFK) word die doel van die Konvent soos volg geformuleer:

... om op grond van ons gemeenskaplike geloof, belydenis en Reformatoriese tradisie

- profetiese getuienisse in die samelewing, en indien nodig, teenoor die samelewing en owerhede te lewer;

- mekaar met raad en hulp by te staan waar dit versoek word;

- moontlike samewerking ten opsigte van gemeenskaplike belange en verantwoordelikhede in die samelewing te koördineer. (Smit, 2009:146; GFK, 1998:1.)

Die kerkregtelike posisionering van deelnemende kerkgemeenskappe lui soos volg:

Die Konvent is 'n byeenkoms waarin kerke gemeenskaplike sake op grond van gemeenskaplike geloof, belydenis en Reformatoriese tradisie behartig, behoudens elke kerk se eie aard, eie etos en eie geskiedenis. Die agenda word daarop gerig om Reformatoriese getuienisse in die naam van die Konvent te lewer. Bepaalde standpunte van deelnemende kerke word nie op ander deelnemende kerke afgedwing nie. Geen kerk sal oor 'n ander kerk enige heerskappy uitoefen nie. (GFK, 1998:1.)

Behalwe getuienisse aan die owerheid oor onder meer die onveiligheid en misdaad in die land, plaasmoorde, werksetiek, MIV en VIGS, is van die belangrikste dinge wat reeds gedoen is, ' $n$ indringende bespreking oor gereformeerdwees in ons tyd en die daarstelling van 'n prosedure waarvolgens al hierdie kerkgemeenskappe geken en betrek kan word ten opsigte van dae van verootmoediging. Daar is ook 'n landswye konferensie oor armoede in 2001 gehou, wat by wyse van handreikings na haweloses na die plaaslike vlak van verskeie kerkgemeenskappe deurgewerk het. Verder is daar 'n belangrike konferensie deur internasionale- en nasionale deskundiges gehou oor die redes vir die golf van misdaad en geweld in die land. Die besluite van hierdie konferensie is aan die verskillende owerheidsvlakke deurgegee. Daar is ook ' $n$ indringende konferensie 
oor die stand van die onderwys in Suid-Afrika gehou, waarna verskeie aspekte met die onderwysowerhede opgeneem is. Die vraag na die betekenis van kerklike eenheid en die wyse waarop dit tot uitdrukking gebring kan word, is steeds hoog op die agenda, soos dit onder meer ook blyk uit die samespreking oor eenheid met die Lutherse Kerk wat in 2009 plaasgevind het (Smit, 2009:146; GFK, 2008:1-38).

Die prosedure waarvolgens die Konvent werk, is ongekompliseerd gestruktureer. Elke kerkgemeenskap kan tien afgevaardigdes benoem en 'n onbeperkte aantal waarnemers. Op elke Konvent word 'n Interimkomitee aangewys, bestaande uit een lid van elke teenwoordige kerkgemeenskap. Die kerkgemeenskap wat aanbied om die volgende Konvent te huisves, wys twee lede aan, wat as voorsitter en skriba by sowel die Interimkomitee as die volgende Konvent optree. 'n Algemene sekretaris, wat telkens aangewys word, tree as kontinueerder op. Die Interimkomitee voer die besluite van die Konvent uit en reël die volgende Konvent (Smit, 2009:145,146; GFK, 1998:2).

\subsection{Die derde (buitenste) sirkel: ekumeniese kontak}

Vanuit die buitenste sirkel maak die GKSA op verskeie vlakke wêreldwyd met die deputate van ander gereformeerde kerke kontak. Hierdie kerklike kontak beoog steeds die doel van uiteindelike kerkeenheid, deur 'n proses van samesprekings en selfs samewerking op terreine waar dit van toepassing kan wees. Hiertoe dien veral ekumeniese liggame soos die International Conference of Reformed Churches (ICRC), die Reformed Ecumenical Council (REC), en die World Reformed Fellowship (WRF) (Smit, 2009:146).

Die GKSA is op die vierjaarlikse konferensie van die ICRC in 2005 tot volwaardige lid van dié ekumeniese liggaam toegelaat. Hoewel die GKSA in 1949 'n stigterslid van die toenmalige Reformed Ecumenical Synod (RES) was, het hy in 1985 bande met dié ekumeniese liggaam vanweë leerstellige besware verbreek. Nadat die RES tot die REC (Reformed Ecumenical Council) herstruktureer is, vaardig die GKSA tans weer verteenwoordigers met waarnemerstatus af na die REC. Die GKSA funksioneer ook as 'n volle deelnemende lid in die WRF vanwaar wêreldwyd, maar veral in Afrika, kontak met buitelandse kerkgemeenskappe gemaak word met wie die GKSA nog nie kerklike eenheid bereik het nie (Smit, 2009:146). 


\section{Beoordeling}

Die ontwikkeling van ekumenisiteit in die Gereformeerde Kerke in Suid-Afrika gedurende die eerste 50 jaar van hierdie kerkgemeenskap se bestaan is gerig op die "eerste fase van ekumenisiteit", naamlik die manifestering van kerkverband. In hierdie konteks kom die dwingendheid van die kerk se ekumeniese roeping wel telkens na vore.

Die tweede fase van 50 jaar bring 'n groter tempo van ekumeniese aktiwiteite mee, waarin veral ook ekumenisiteit met ander kerkverbande in Suid-Afrika en elders tot stand kom. Die ekumeniese aktiwiteit met ander kerkverbande fokus egter steeds op "een kerkverband", in die besonder op die faktore wat die betrokke kerkgemeenskappe uitmekaar hou.

Tydens die derde halfeeu, veral die laaste dekade daarvan, vind 'n vaartversnelling plaas ten opsigte van ekumenisiteit met kerkgemeenskappe regoor die hele wêreld. Die ekumeniese gesprek word egter steeds hoofsaaklik op kerkgemeenskappe gerig met dieselfde belydenisgrondslag en gesamentlike belange.

Uit die voorafgaande blyk dat die GKSA hulleself nie as 'n kerkgemeenskap beskou wat alleen en uitsluitlik oor die waarheid van die Woord beskik nie. Kerklike isolasie word geensins nagestreef nie; trouens, dit is duidelik dat kerklike isolasie deur die GKSA op grond van die Woord bestry word. Die dryfveer om kerkgemeenskappe in eenheid saam te snoer - in die binneland én in die buiteland - was van vroeg af deel van die Gereformeerde kerkbeskouing. Die norm van hierdie dryfveer is kennelik nie kerklike gebruike (vanweë kultuursituering), of tyds- of plekbepalings nie, maar Skrifverankerdheid. Binne hierdie kader is, waar kerkeenheid nog nie kon realiseer nie, ruimte geskep vir kerklike samewerking. Dit blyk dat Gereformeerdes die verlies van kerkeenheid nie slegs as ' $n$ ergernis nie, maar ook as 'n sonde aanvoel. Omdat die kerk van die Here op aarde vir die GKSA wesenlik één is, is die kerk vanweë die sondeverskeurdheid ook geroep om in die praktyk steeds meer één te word.

Tog is daar 'n opvallende leemte. Die betekenisaspek wat Jesus aan die begrip oikoumené toevoeg (Matt. 24:14), naamlik die verkondiging van die evangelie aan "al die nasies" in die "hele wêreld" (oikoumené) met die oog op die "toekomstige wêreld" (Heb. 2:5) is in die verlede nie genoeg beklemtoon nie, maar eintlik verskraal. Die GKSA het die doelpunt van ekumenisiteit in die praktyk hoofsaaklik 
op die enger kerkgemeenskap in die wêreld gerig waaruit konflik geweer moet word, ten koste van wêreldwye koninkryksgemeenskap wat gekenmerk word deur eenheid in versoende diversiteit (vgl. Bosch, 1992:465). Omdat die klem op die vorming van kerkverband onder bestaande kerkgemeenskappe gelê is, was daar onvoldoende begrip vir die ekumeniese aard van die sendingopdrag, ' $n$ ekumenisiteit wat op die wêreld gerig is. Per slot van rekening is dit die roeping van die kerk om die diepste konflik met die wêreld te oorbrug en die wêreld met versoenende, transformerende krag te benader - 'n benaderingswyse wat wêreldlinge as deel van 'n nuwe gemeenskap hervorm met nuwe hoop en 'n nuwe roeping (vgl. West, 1971:270). Die vervulling van die ideaal van 'n Skriftuurlike ekumenisiteit, waarin vir sending tegelyk vir eenheid, en vir eenheid vir sending beteken, het nie in die GKSA tot sy reg gekom nie (vgl. Saayman, 1980:144).

Ekumenisiteit in sending en sending in ekumenisiteit maak die kerk in die wêreld bekend as die liggaam van Christus binne die bakens van eenheid, katolisiteit, apostolisiteit en heiligheid. Sodoende word die roeping van die kerk as die sin van die geskiedenis van die mensheid bekend gestel. Op hierdie wyse word die kerk in die uitvoering van God se raad in diens van die mensheid gestel, juis as 'n teken van die nuwe eenheid van 'n nuwe mensheid op 'n nuwe aarde. Hiertoe is ekumenisiteit en sending essensieel op mekaar betrokke as die kerk se volhardende trou aan sy Verlosser en sy hoogste vorm van diens aan die mensheid (Smit, 2006:111). Dat hierdie aspek as 'n leemte in die ontwikkeling van ekumenisiteit in die GKSA aangemerk moet word, doen nie af aan die erns waarmee die eenheid van die kerk wêreldwyd binne gereformeerde verband bejeën word nie.

\section{Geraadpleegde bronne}

BERKOUWER, G.C. 1976. The church. Grand Rapids: Eerdmans.

$\mathrm{BOSCH}$, D.J. 1992. Transforming mission: paradigm shifts in theology of mission. Maryknoll: Orbis.

BRONKHORST, A.J. 1960. Oecumene, oecumenish. (In Grosheide, F.W. \& Van Itterzon, G.P., reds. Christelijke Encyclopedie. Bd. 5. 2e hers. dr. Kampen: Kok. p. 243.)

CALVYN, J. 1972. Uitlegging op den eersten en tweeden zendbrief van Paulus aan de Corinthiërs. 2e dl. Vert. deur A.M. Donner. Kampen: De Groot.

CALVYN, J. 1992 [1559]. Institusie van die Christelike godsdiens. Potchefstroom: CJBF.

DU TOIT, S., ed. 1959. Eeufees te Rustenburg. Potchefstroom: P.H. Drukkery. 
GEREFORMEERDE KERKE IN SUID-AFRIKA. 1862. Handelingen van de eerste algemeene sijnodale vergadering der Gereformeerde Kerk, van de Zuid-Afrikaansche Republiek, den Oranje Vrijstaat en de Kaap-Kolonie in Zuid-Afrika. Kaapstad: Solomon.

GEREFORMEERDE KERKE IN SUID-AFRIKA. 1866. Handelingen van de derde algemeene synodale vergadering der Gereformeerde Kerk, van de Zuid-Afrikaansche Republiek, den Oranje Vrijstaat en de Kaap-Kolonie in Zuid-Afrika. Kaapstad: Solomon.

GEREFORMEERDE KERKE IN SUID-AFRIKA. 1873. Handelingen van de vijfde algemeene synodale kerkvergadering samengesteld uit al de Gereformeerde gemeenten van Zuid-Afrika. Kaapstad: Solomon.

GEREFORMEERDE KERKE IN SUID-AFRIKA. 1876. Handelingen van de zesde algemeene synodale kerkvergadering samengesteld uit al de Gereformeerde gemeenten van Zuid-Afrika. Kaapstad: Solomon.

GEREFORMEERDE KERKE IN SUID-AFRIKA. 1879. Handelingen van de zevende algemeene synodale kerkvergadering samengesteld uit al de Gereformeerde gemeenten van Zuid-Afrika. Kaapstad: Solomon.

GEREFORMEERDE KERKE IN SUID-AFRIKA. 1904. Handelingen van de veertiende algem. synodale kerkvergadering samengesteld uit al de Gereformeerde gemeenten van Zuid-Afrika. Burgersdorp: De Stem.

GEREFORMEERDE KERKE IN SUID-AFRIKA. 1913. Handelingen van de zeventiende algemene synodale vergadering van de Gereformeerde gemeenten van Zuid-Afrika. Pretoria: Van der Reyden.

GEREFORMEERDE KERKE IN SUID-AFRIKA. 1916. Handelingen van de achttiende algemene synodale vergadering van de Gereformeerde gemeenten van Zuid-Afrika. Pretoria: Van der Reyden.

GEREFORMEERDE KERKE IN SUID-AFRIKA. 1920. Handelinge van die twintigste algemene sinodale vergadering van die Gereformeerde gemeentes in Suid-Afrika. Bloemfontein: Nasionale Pers.

GEREFORMEERDE KERKE IN SUID-AFRIKA. 1924. Handelinge van die eenen-twintigste sinodale vergadering van die Gereformeerde Kerke in SuidAfrika. Bloemfontein: Nasionale Pers.

GEREFORMEERDE KERKE IN SUID-AFRIKA. 1927. Handelinge van die tweeen-twintigste sinodale vergadering van die Gereformeerde Kerke in SuidAfrika. Bloemfontein: Nasionale Pers.

GEREFORMEERDE KERKE IN SUID-AFRIKA. 1930. Handelinge van die drieen-twintigste sinodale vergadering van die Gereformeerde Kerke in SuidAfrika. Potchefstroom: Die Weste.

GEREFORMEERDE KERKE IN SUID-AFRIKA. 1933. Handelinge van die vieren-twintigste sinodale vergadering van die Gereformeerde Kerke in SuidAfrika. Potchefstroom: Die Weste.

GEREFORMEERDE KERKE IN SUID-AFRIKA. 1936. Handelinge van die vyfen-twintigste sinodale vergadering van die Gereformeerde gemeentes in Suid-Afrika. Potchefstroom: Die Weste.

GEREFORMEERDE KERKE IN SUID-AFRIKA. 1939. Handelinge van die 26ste sinodale vergadering van die Gereformeerde gemeentes in Suid-Afrika. Potchefstroom: Die Weste.

GEREFORMEERDE KERKE IN SUID-AFRIKA. 1942. Handelinge van die 27ste sinodale vergadering van die Gereformeerde gemeentes in Suid-Afrika. Potchefstroom: Die Weste. 
GEREFORMEERDE KERKE IN SUID-AFRIKA. 1945. Handelinge van die 28ste sinodale vergadering van die Gereformeerde gemeentes in Suid-Afrika. Potchefstroom: Die Weste.

GEREFORMEERDE KERKE IN SUID-AFRIKA. 1946. Handelinge van die 29ste sinodale vergadering van die Gereformeerde gemeentes in Suid-Afrika. Potchefstroom: Die Weste.

GEREFORMEERDE KERKE IN SUID-AFRIKA. 1949. Handelinge van die 30ste sinodale vergadering van die Gereformeerde gemeentes in Suid-Afrika. Pretoria: V\&R.

GEREFORMEERDE KERKE IN SUID-AFRIKA. 1952. Handelinge van die 31ste sinodale vergadering van die Gereformeerde gemeentes in Suid-Afrika. Pretoria: V\&R.

GEREFORMEERDE KERKE IN SUID-AFRIKA. 1955. Handelinge van die 32ste sinodale vergadering van die Gereformeerde gemeentes in Suid-Afrika. Pretoria: V\&R.

GEREFORMEERDE KERKE IN SUID-AFRIKA. 1958. Handelinge van die 33ste sinodale vergadering van die Gereformeerde gemeentes in Suid-Afrika. Potchefstroom: Herald.

GEREFORMEERDE KERKE IN SUID-AFRIKA. 1961. Handelinge van die vieren-dertigste sinodale vergadering van die Gereformeerde Kerk in SuidAfrika. Potchefstroom: Herald.

GEREFORMEERDE KERKE IN SUID-AFRIKA. 1967. Handelinge van die sesen-dertigste sinodale vergadering van die Gereformeerde Kerk in SuidAfrika. Potchefstroom: Herald.

GEREFORMEERDE KERKE IN SUID-AFRIKA. 1970. Handelinge van die sewe-en-dertigste sinodale vergadering van die Gereformeerde Kerk in Suid-Afrika. Potchefstroom: Herald.

GEREFORMEERDE KERKE IN SUID-AFRIKA. 1979. Handelinge van die veertigste sinode te Potchefstroom. Potchefstroom: Herald.

GEREFORMEERDE KERKE IN SUID-AFRIKA. 1994. Handelinge van die vyfen-veertigste nasionale sinode te Potchefstroom. Potchefstroom: Herald.

GEREFORMEERDE KERKE IN SUID-AFRIKA. 1997. Handelinge van die sesen-veertigste nasionale sinode te Potchefstroom. Pretoria: V\&R.

GEREFORMEERDE KERKE IN SUID-AFRIKA. 2000. Handelinge van die sewe-en-veertigste nasionale sinode te Potchefstroom. Pretoria: V\&R.

GEREFORMEERDE KERKE IN SUID-AFRIKA. 2003. Handelinge van die agten-veertigste nasionale sinode te Potchefstroom. Pretoria: V\&R.

GEREFORMEERDE KERKE IN SUID-AFRIKA. 2006. Handelinge van die GFK nege-en-veertigste nasionale sinode te Potchefstroom. Pretoria: V\&R.

\section{GKSA}

kyk KONVENT VAN REFORMATORIESE KERKE IN SUIDER-AFRIKA

kyk GEREFORMEERDE KERKE IN SUID-AFRIKA

GOOSEN, G. 1993. Bringing churches together - a popular introduction to ecumenism. Revised and enlarged ed. Geneve: WCC.

KERSTEN, G.H. 1961. Kerkelijk handboekje. 2e dr. Utrecht: De Banier.

KONVENT VAN REFORMATORIESE KERKE IN SUIDER-AFRIKA. 1998. Grondslag en funksionering van die Konvent van Reformatoriese Kerke in Suider-Afrika. (Ongepubliseer.) 
KONVENT VAN REFORMATORIESE KERKE IN SUIDER-AFRIKA. 2008. Conventus reformatus: dokumentebundel saamgestel by geleentheid van die Konvent se tiende bestaansjaarviering. (Ongepubliseer.)

KÜNG, H. 1978. The church. London: Search.

NIJENHUIS, W. 1959. Calvinus oecumenicus - Calvijn en de eenheid der kerk in het licht van zijn briefwisseling. Gravenhage: Nijhoff.

PELSER, P.J. 1976. Die roeping tot sigbaarmaking van die katolisiteit van die Kerk. Potchefstroom: PU vir CHO. (Th.D.-proefskrif.)

SAAYMAN, W.A. 1980. Unity and mission - a study of the concept of unity in ecumenical discussions since 1961 and its influence on the world mission of the church. Stellenbosch: University of Stellenbosch. (D.Th. dissertation.)

SMIT, C.J. 2006. Ekumenisiteit as 'n Skrifgefundeerde raamwerk vir kerklike eenheid - ook op die gebied van sendingwerk. In die Skriflig, 42(2):89115.

SMIT, C.J. 2009. Die GKSA en ekumenisiteit - kerkeenheid oor die wêreld heen. (In Vorster, K. et al., red. Uit Dankbaarheid - 1959-2009. Pretoria: V\&R. p. 139-147.)

SNYMAN, W.J. 1977. Nuwe en ou dinge. Potchefstroom: Pro Rege.

TKR

$k y k$ TUSSENKERKLIKE RAAD

TUSSENKERKLIKE RAAD. 2004. Grondslag. (Ongepubliseer.)

WEST, C.C. 1971. The power to be human: toward a secular theology. New York: Macmillan.

\section{Kernbegrippe:}

ekumenisiteit

kerkeenheid

kerkgemeenskap

korrespondensie

\section{Key concepts:}

church community

church unity

correspondence

ecumenism 
